\title{
Ocena zależności między wizerunkiem robota a zaufaniem do robota $w$ świetle koncepcji doliny niesamowitości, na przykładzie zawodów o wysokim prestiżu społecznym
}

\author{
Tomasz Kruszewski \\ ORCID 0000-0002-3062-9454 \\ Katedra Kognitywistyki, Instytut Badań Informacji i Komunikacji \\ Uniwersytet Mikołaja Kopernika w Toruniu
}

\begin{abstract}
Abstrakt
Cel/Teza: Głównym celem artykułu jest weryfikacja tezy o istnieniu zjawiska doliny niesamowitości w ocenie zaufania do robotów, na przykładzie robotów reprezentujących wybrane zawody o wysokim poważaniu społecznym. Sprawdzono także zależność poczucia bezpieczeństwa człowieka od rodzaju usług wykonywanych przez roboty.

Koncepcja/Metody badań: Badanie przeprowadzono metodą sondażu (survey’u) na grupie celowej studentów kilku kierunków z zakresu nauk społecznych i humanistycznych, w którym wykorzystano kwestionariusz ankiety zawierający wizerunki robotów antropomorficznych o różnym stopniu podobieństwa do człowieka. Ocenie zaufania podlegały roboty wykonujące sześć zawodów: sprzedawca, robotnik wykwalifikowany, lekarz, pielęgniarka, profesor uczelni, księgowa. Wnioskowanie przeprowadzono na podstawie rozkładów ocen oraz testu niezależności chi-kwadrat.

Wyniki i wnioski: Badanie potwierdziło istnienie zjawiska doliny niesamowitości oraz zależności między poziomem zaufania i bezpieczeństwa a rodzajem pracy wykonywanej przez robota.

Oryginalność/Wartość poznawcza: Według wiedzy autora, dotychczas nie badano w Polsce zjawiska doliny niesamowitości z uwzględnieniem ról zawodowych robotów jako zmiennej niezależnej.
\end{abstract}

\section{Słowa kluczowe}

Dolina niesamowitości. Emocje. Percepcja twarzy. Roboty antropomorficzne. Role zawodowe. Sztuczna inteligencja.

Otrzymany: 11 lipca 2019. Zrecenzowany: 14 września 2019. Poprawiony: 30 września 2019. Zaakceptowany: 28 października 2019.

\section{Wprowadzenie}

Film To mój przyjaciel robot (niem. Hi, A.I. - Liebesgeschichten aus der Zukunft) w reżyserii Isabelli Willinger ukazuje relacje na poziomie poznawczym i emocjonalnym, które zachodzą pomiędzy ludźmi a robotami wyposażonymi w sztuczną inteligencję. Film powstał w 2019 r. i przez wielu widzów jest traktowany jako futurystyczna opowieść. Tymczasem przyszłość, w której sztuczna inteligencja pełni określone role społeczno-zawodowe staje się już teraźniejszością. Kontakt telefoniczny lub wideofoniczny z działem obsługi klientów w bankach lub w firmach telekomunikacyjnych coraz częściej następuje w relacji człowiek - sztuczna 
inteligencja. Chatboty w internetowej reklamie albo sprzedaży przez wiele podmiotów gospodarczych są traktowane jako jedne z podstawowych narzędzi kontaktów handlowych. Są też testowane w usługach informacyjnych jako wirtualni asystenci, np. w muzeach czy bibliotekach (Wójcik, 2018a, 110-111). Tzw. słaba sztuczna inteligencja, czyli operacje systemu komputerowego naśladującego w ograniczonym zakresie inteligentne zachowanie (Iafrate, 2018, 99) towarzyszy nam już teraz. Czas silnej sztucznej inteligencji, czyli takiej, która potrafi wykonać większość lub wszystkie intelektualne zadania, które wykonuje człowiek (Siau \& Wang, 2018, 53), prawdopodobnie nastąpi za życia czytelników tego artykułu.

Składnikiem rozwoju sztucznej inteligencji jest antropomorfizacja, czyli przypisywanie lub nadawanie cech ludzkich, takich jak wygląd, zachowanie, myślenie, przedmiotom albo istotom niebędącym człowiekiem. Takimi przedmiotami, a dokładniej urządzeniami, którym poświęcono niniejszy artykuł, są roboty usługowe posiadające cechy antropomorficzne i jednocześnie funkcjonujące w świecie fizycznym (w odróżnieniu od chatbotów aktywnych w przestrzeni wirtualnej).

Omówione w artykule badania mają charakter pilotażowy i są ukierunkowane na poznanie zależności między poczuciem bezpieczeństwa i zadowolenia klientów, którym bezpośrednio świadczone są usługi robotów wykazujących cechy antropomorficzne. Relacje „twarzą w twarz” w stosunkowo niedalekiej przyszłości będą zachodziły w obrębie bardzo różnych aktywności, w tym aktywności zawodowych - również z sektora informacji naukowej i edukacji. Założono, że poczucie bezpieczeństwa w sytuacji przebywania w towarzystwie robota i sympatia do niego mogą być zależne od zjawiska psychologicznego, które określa się mianem doliny niesamowitości (niesamowitej doliny, ang. uncanny valley). Zjawisko to można opisać następująco: nasilający się bodziec w postaci wzrastającego podobieństwa robota do człowieka wytwarza u niego wzrastającą pozytywną reakcję emocjonalną na bodziec, ale kiedy podobieństwo zbliża się do doskonałości, emocjonalna reakcja jednostki gwałtownie spada i staje się silnie negatywna (Burleigh et al., 2013, 1). Ten spadek to tzw. dolina niesamowitości - zjawisko, którego nazwę wprowadził Masahiro Mori (Mori, 2012, 98).

Badacze w różny sposób interpretują przyczyny zjawiska doliny niesamowitości, niektórzy korygują ustalenia innych badaczy, inni zaprzeczają jego istnieniu (MacDorman \& Chattopadhyay, 2016, 190). Jednak badania prowadzone różnymi metodami, w różnym czasie i wśród osób pochodzących z różnych kultur nie dają jednoznacznej odpowiedzi. Uzasadnienia zjawiska niesamowitej doliny formułowane są w kontekście teorii różnych dyscyplin naukowych, od humanistycznych po badania funkcjonalne i strukturalne mózgu (Burleigh et al., 2013, 2-4; Mathur \& Reichling, 2016; Yamada et al., 2013, 20-21). Trzeba dodać, że na wyrazistość doliny niesamowitości wpływa wiele czynników, takich jak cechy kulturowo-społeczne uczestników badań, wcześniejsze ich doświadczenia z robotami, a także cechy osobowościowe (Bartneck et al., 2008, 78). Powoduje to, że uzyskiwanych wyników badań nie należy interpretować jak danych bezwzględnych. Stąd w niniejszym artykule szczegółowo została przedstawiona metodologia przeprowadzonego badania, aby ukazać jej mocne i słabe strony oraz podjąć głos w dyskusji nad standaryzacją badań dotyczących omawianego zjawiska. 


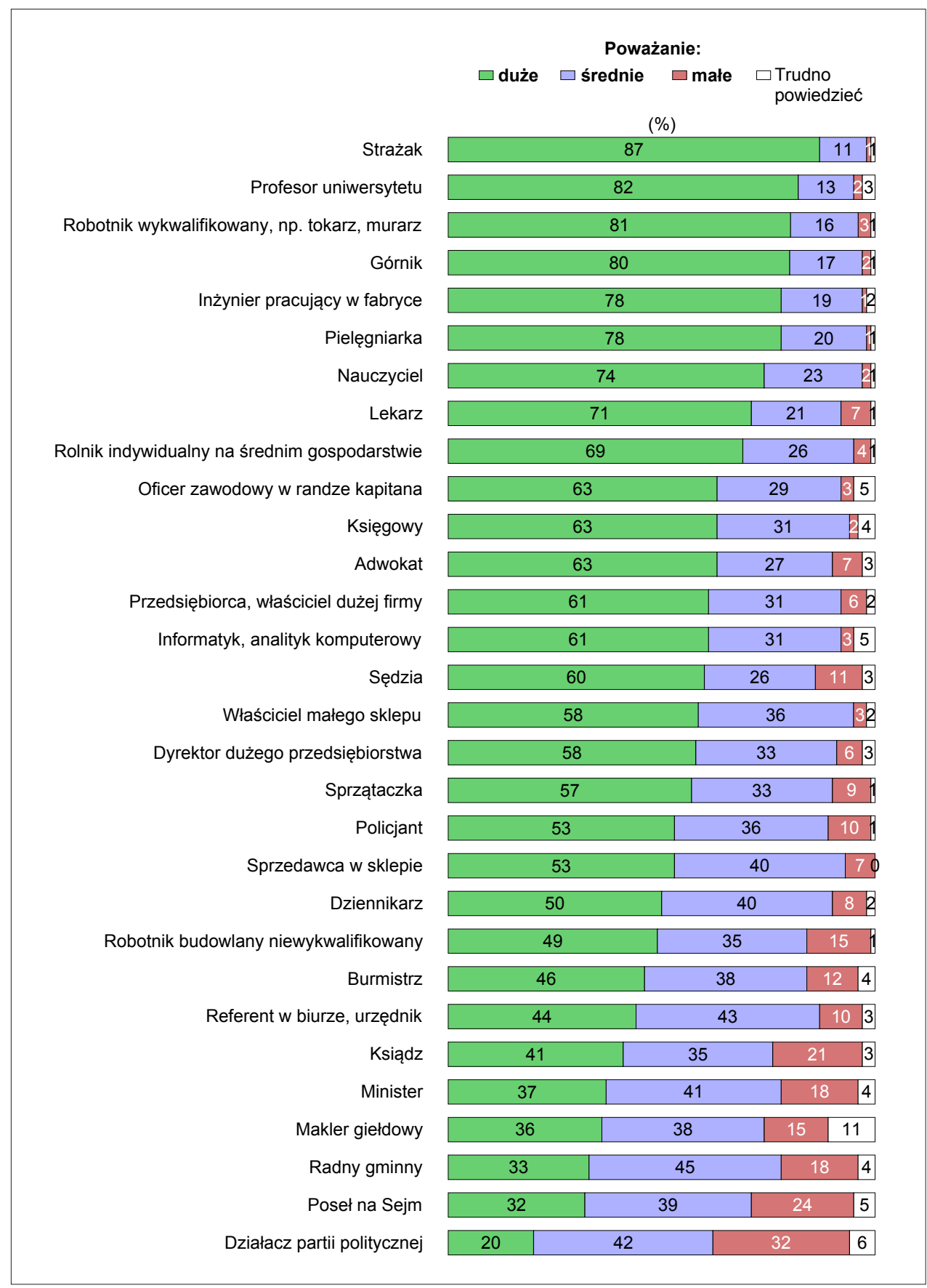

Rys. 1. Hierarchia zawodów według poważania społecznego Źródło: CBOS, 2013. 
Zagadnienia robotyzacji i automatyzacji są przedmiotem zainteresowania także w kontekście pracy, jaką wykonuje człowiek. Stan badań nad sztuczną inteligencją i jej wykorzystaniem w procesach zarządzania informacją w bibliotece był ostatnio przedmiotem zainteresowania Magdaleny Wójcik (Wójcik, 2018b, 5-15). Badacze ponadto poszukują potencjalnych konsekwencji, które uwidaczniają się u obserwatora (Mathur \& Reichling, 2016, 22-23). Upodobnienie robota do człowieka prawdopodobnie wywoływać też może u niego utratę poczucia bezpieczeństwa wynikającą z odczuwania zagrożenia byciem zastąpionym. Badania Carla Benedikta Freya i Michaela A. Osborne'a z Oxford University wykazały, że tylko w zakresie wykonywania czynności zawodowych są do tego wyraźne podstawy. Blisko 70\% miejsc pracy jest mniej lub bardziej zagrożonych automatyzacją i komputeryzacją (Frey \& Osborne, 2013, 37).

Zauważa się, że ocena jakości usług wiąże się ze społecznym prestiżem zawodów związanych ze świadczeniem tych usług. W najnowszych opublikowanych wynikach badań CBOS dotyczących rankingu zawodów prestiżowych, które przeprowadzono w 2013 r. na liczącej 904 osoby reprezentatywnej próbie losowej dorosłych mieszkańców Polski, wyodrębniono 30 zawodów. Największym poważaniem cieszył się strażak (87\% deklaracji dużego uznania), tuż za nim uplasowali się profesor uniwersytecki (82\% deklaracji dużego szacunku) oraz robotnik wykwalifikowany (np. murarz, tokarz - 81\%). Wysokie pozycje w hierarchii uzyskali ponadto przedstawiciele zawodów cechujących się wysoką użytecznością społeczną, m.in. pielęgniarka i lekarz (odpowiednio 78\% i 71\%). Niższe pozycje, ale nadal z przewagą opinii pozytywnych i dające miejsce w pierwszej dwudziestce rankingu zawodów o wysokim prestiżu społecznym, zajęli księgowa (63\%) i sprzedawca (51\%) (CBOS). Pełny ranking prestiżowych zawodów ukazuje rysunek 1.

\section{Organizacja i metody badań}

Badanie przeprowadzono od marca do maja 2019 r. na grupie celowej studentów kilku kierunków studiów z zakresu nauk humanistycznych i społecznych w dwóch toruńskich uczelniach wyższych (komunikacja i psychologia w biznesie - Uniwersytet Mikołaja Kopernika i Wyższa Szkoła Bankowa, architektura informacji, wojskoznawstwo, zarządzanie informacją - wszystkie UMK). W badaniu uczestniczyli respondenci, którzy w toku kształcenia akademickiego mieli kontakt z wiedzą dotyczącą sztucznej inteligencji. Założono, że dzięki takiemu doborowi próby badawczej, reakcje respondentów związane z doliną niesamowitości będą bardziej koherentne niż w przypadku respondentów wybieranych losowo. Wiek respondentów mieścił się w zakresie od 20 do 23 lat. Liczba wypełnionych kwestionariuszy ankiety: $n=105$, w tym prawidłowo wypełnionych $n=99$. Rozkład płci: nkobiet $=68$; nmężczyzn=31. Kwestionariusz ankiety był przekazywany respondentom w bezpośrednim kontakcie. Na jego wypełnienie mieli czas nieograniczony, był jednak zwracany badaczowi w ciągu nie więcej niż 15 minut.

Na podstawie wspomnianego wcześniej Komunikatu z badań: BS/164/2013: prestiz zawodów przedstawionego przez CBOS (CBOS, 2013) z hierarchii zawodów według poważania społecznego wybrano sześć zawodów, które plasowały się w górnej części rankingu. Byli to: profesor, pielęgniarka, robotnik, księgowy, sprzedawca, lekarz. W wyborze profesji kierowano się także typologią zawodów utworzoną na potrzeby badania, w której 
wyróżniono trzy umowne grupy zawodów: zawody usługowe (sprzedawca, robotnik wykwalifikowany, zawody związane z wiedzą (profesor, księgowa) oraz zawody związane z usługami medycznymi (lekarz, pielęgniarka), które mogą być oceniane przez klientów i pacjentów jako inwazyjne. Każdej roli zawodowej przypisane zostały trzy rysunki z robotem o różnym stopniu podobieństwa do człowieka (Rys. 2). Robot o stopniu podobieństwa $0 \% \mathrm{w}$ każdym pytaniu był reprezentowany przez ten sam rysunek [a]; robot o stopniu podobieństwa $50 \%$ - dwoma wizerunkami, po jednym w wersji męskiej i żeńskiej [b] oraz robot ze $100 \%$ podobieństwem przez sześć wizerunków, które zostały dostosowane do przeciętnego wyglądu osób dla danej roli zawodowej. Tutaj obie płcie były wyrażone arbitralnie w trzech egzemplifikacjach. Każda z sześciu ról zawodowych została oceniona pod względem sympatii (i pośrednio - poczucia bezpieczeństwa) przez ocenę chęci respondenta do współpracy z robotem oraz chęci pozyskania od niego usług; oceny były wyrażane za pomocą trójstopniowej skali: najmniej chętnie (-1); mniej/średnio chętnie (0); najchętniej (1) (zob. załącznik: kwestionariusz ankiety).

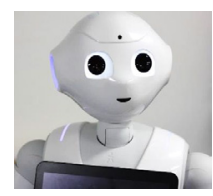

[a] stopień podobieństwa robota: $0 \%$

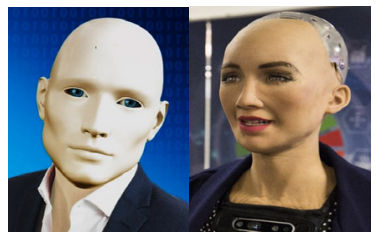

[b] stopień podobieństwa robota: $50 \%$

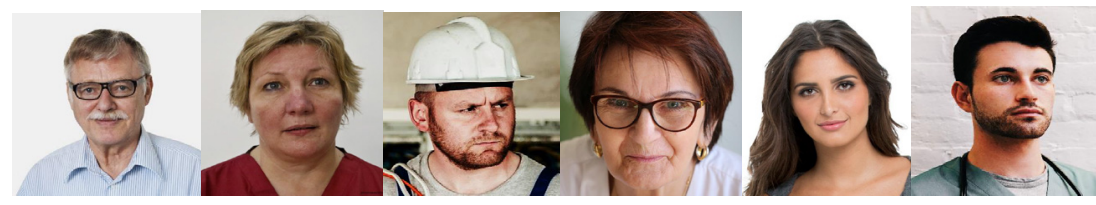

[c] stopień podobieństwa robota: 100\% (od lewej: profesor uniwersytecki, pielęgniarka, robotnik wykwalifikowany, księgowy, sprzedawca, lekarz)

Rys. 2. Wizerunki robota użyte w badaniu (ilustracje pochodzą z domeny publicznej - są objęte prawami autorskimi zgodnie z licencją CC BY 2.0)

Proces analizy danych przeprowadzono w dwóch etapach, pierwszy skupił się na graficznej interpretacji rozkładów ocen z podziałem na zawody. Jak wcześniej wspomniano, w koncepcji doliny niesamowitości zakłada się istnienie minimum obserwowanego w momencie, w którym wizerunek robota zaczyna charakteryzować się większym podobieństwem do człowieka niż akceptowane przez respondenta. Moment ten (dolina niesamowitości) nie jest stały - należy założyć, że jest zależny m.in. od indywidualnych cech respondenta, 
wieku, jego wcześniejszych doświadczeń, w tym wcześniejszych interakcji z robotami. Istnieją przesłanki ku temu, aby identyfikacja tego momentu - w pełnym badaniu - była przeprowadzona na podstawie oceny wielu fotografii lub nagrań tego samego robota, na którego wizerunek w czasie badania nakładane byłyby niewielkie zmiany upodabniającego go do człowieka. W badaniu omówionym w niniejszym artykule posłużono się względnie małą liczbą fotografii, odpowiadającą trzem stopniom podobieństwa robota do człowieka. Jednak założono, że będzie możliwa obserwacja wycofania respondentów w ocenie robota, którego wizerunek stanowi mieszankę robota i człowieka (wizerunek robota o 50\% stopniu podobieństwa do człowieka). A zatem założono, że taki robot będzie obdarzony mniejszym zaufaniem niż inne. Taka interpretacja nie decyduje o stwierdzeniu wystąpienia zjawiska doliny niesamowitości w myśl metodyki badań prezentowanych w zagranicznej literaturze, jednak pozwala sądzić, że takie samo wycofanie może zostać zaobserwowane, gdyby wizerunek robota odtworzy się na wielu fotografiach z powolnym przechodzeniem ze stanu braku podobieństwa do człowieka do stanu całkowitego podobieństwa do człowieka. Spadek zaufania jest interpretowany jako przesłanka do dalszych badań, które mogłyby wskazać na istnienie doliny niesamowitości.

W drugiej części badania skupiono się na weryfikacji zależności między wizerunkiem robota a stopniem zaufania do robota. Ocena zależności między zmiennymi została przeprowadzona przy pomocy testu niezależności chi-kwadrat na różnych poziomach. Celem autora było sprawdzenie, czy dalsze badania dotyczące doliny niesamowitości powinny być prowadzone z uwzględnieniem podziału na zawody. Zarówno teoria, jak i intuicja podpowiadają, że zaufanie przypisywane do robota może być zależne od miejsca, w którym on został uruchomiony i obszaru życia człowieka, któremu ma asystować (dla przykładu: szpital/szkoła).

Do weryfikowania hipotez o niezależności dwóch zmiennych dyskretnych wykorzystano test niezależności chi-kwadrat. Statystykę testu wyraża wzór [1], wartości krytyczne $\left[\mathrm{X}^{2}{ }_{\alpha, v}\right]$ zostały odczytane z tablic rozkładu chi-kwadrat, dla stopni swobody: $v=(r-1) *(k-1)$ oraz poziomu istotności $\alpha=0.05$. Zapis formalny hipotez (oznaczenia przyjęte za: Sobczyk, 2012, 227-237) jest następujący:

$\mathrm{H}_{0}: \mathrm{E}\left(\mathrm{n}_{\mathrm{ij}}\right)=\mathrm{E}\left(\check{\mathrm{n}}_{\mathrm{ij}}\right)$; cechy X i Y są niezależne

$\mathrm{H}_{1}: \mathrm{E}\left(\mathrm{n}_{\mathrm{ij}}\right) \neq \mathrm{E}\left(\check{n}_{\mathrm{ij}}\right)$; cechy X i Y nie są niezależne, gdzie:

$\mathrm{E}$ - operator nadziei matematycznej,

$\check{n}_{\mathrm{ij}}$ - liczebności teoretyczne z tablicy niezależności, spełniające warunek stochastycznej niezależności zmiennych $X$ i $Y$.

$$
X^{2}=\sum_{i=1}^{k} \sum_{j=1}^{r} \frac{\left(n_{i j}-\check{n}_{i j}\right)^{2}}{\check{n}_{i j}}
$$

Siła korelacji między zmiennymi (w przypadku odrzucenia $\mathrm{H}_{0}$ na rzecz $\mathrm{H}_{1}$ ) została oceniona na podstawie współczynnika C Pearsona opartego na statystyce chi-kwadrat [2].

[2] $\quad C=\sqrt{\frac{X^{2}}{X^{2 \cdot n}}}$ 


\section{Wyniki badań}

\subsection{Ocena zależności między wizerunkiem robota a zaufaniem wobec robota}

Rysunek 3 przedstawia rozkład ocen dotyczących zaufania do robota według ról zawodowych reprezentowanych przez robota oraz stopnia podobieństwa jego wizerunku do człowieka.

[a] stopień podobieństwa robota: $0 \%$

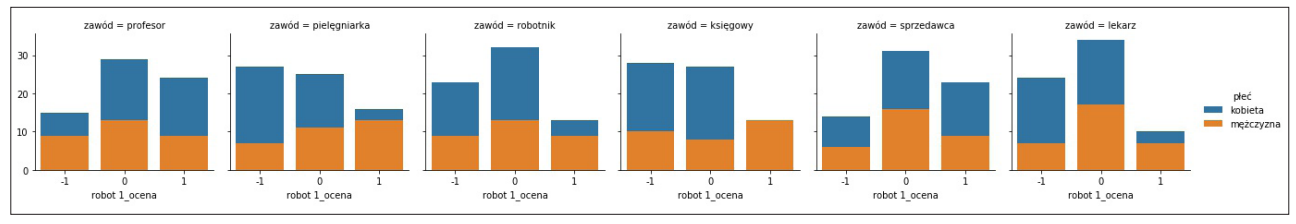

[b] stopień podobieństwa robota: $50 \%$

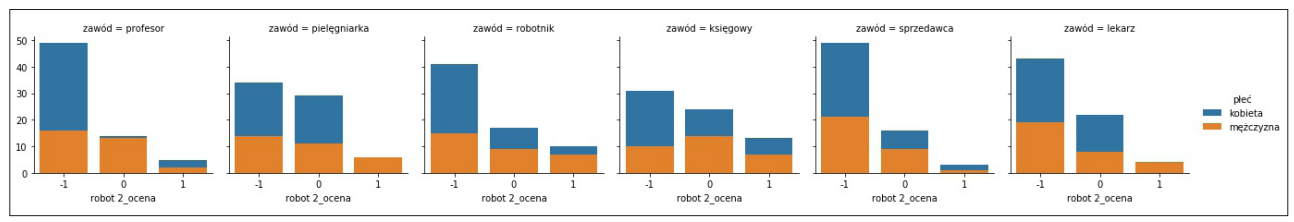

[c] stopień podobieństwa robota: $100 \%$

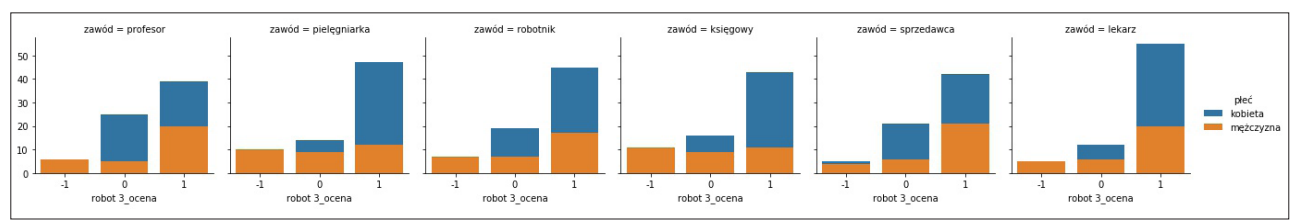

Rys. 3. Rozkład ocen robotów [a-c] według zawodu i płci dla skali oceny:

[-1: najmniej chętnie], [0: mniej/średnio chętnie], [1: najchętniej]

W tabelach 1 i 2 zestawiono dane o rozkładzie częstości występowania zmiennej stopień zaufania do robota w ujęciu ogólnym i z wyszczególnieniem sześciu zawodów oraz wzrastającym stopniem podobieństwa robota do człowieka.

Tab. 1. Rozkłady częstości zmiennej stopień zaufania do robota - ogólnie*

\begin{tabular}{|c|c|c|c|c|c|c|c|}
\cline { 2 - 8 } \multicolumn{1}{c|}{} & \multicolumn{7}{c|}{ stopień zaufania do robota } \\
\hline \multirow{2}{*}{$\begin{array}{c}\text { robot } \\
\text { robot } 0 \%\end{array}$} & najmniej & $\%$ & mniej/średnio & $\%$ & chętnie & $\%$ & suma \\
\cline { 2 - 9 } & 179 & 30.13 & 256 & 43.32 & 159 & 26.63 & 594 \\
\hline robot $50 \%$ & 342 & 57.57 & 186 & 31.47 & 66 & 11.06 & 594 \\
\hline robot 100\% & 73 & 12.29 & 149 & 25.21 & 372 & 62.31 & 594 \\
\hline suma & - & 100 & - & 100 & - & 100 & \\
\hline
\end{tabular}

* W tabeli przedstawiono oceny zagregowane, tj. dla każdego robota zsumowano oceny dla każdej roli zawodowej dla każdego respondenta (taczna liczba ocen $n=6 * 99=594$ ). 
Tab. 2. Rozkłady częstości zmiennej stopień zaufania do robota dla poszczególnych ról zawodowych

\begin{tabular}{|c|c|c|c|c|c|c|}
\hline \multirow{2}{*}{ grupa zawodowa } & \multicolumn{5}{|c|}{ stopień zaufania do robota 1 [0\% podobieństwa] } \\
\cline { 2 - 8 } & $\begin{array}{c}\text { najmniejsze } \\
\text { zaufanie }\end{array}$ & $\%$ & $\begin{array}{c}\text { średnie } \\
\text { zaufanie }\end{array}$ & $\%$ & chętnie & $\%$ \\
\hline księgowy & 38 & 21.23 & 35 & 13.67 & 26 & 16.35 \\
\hline lekarz & 31 & 17.32 & 51 & 19.92 & 17 & 10.69 \\
\hline pielęgniarka & 34 & 18.99 & 36 & 14.06 & 29 & 18.24 \\
\hline profesor & 24 & 13.41 & 42 & 16.41 & 33 & 20.75 \\
\hline robotnik & 32 & 17.88 & 45 & 17.58 & 22 & 13.84 \\
\hline sprzedawca & 20 & 11.17 & 47 & 18.36 & 32 & 20.13 \\
\hline suma & 179 & & 256 & & 159 & \\
\hline
\end{tabular}

\begin{tabular}{|c|c|c|c|c|c|c|}
\hline \multirow{2}{*}{ grupa zawodowa } & \multicolumn{6}{|c|}{ stopień zaufania do robota 2 [50\% podobieństwa] } \\
\cline { 2 - 8 } & $\begin{array}{c}\text { najmniejsze } \\
\text { zaufanie }\end{array}$ & $\%$ & $\begin{array}{c}\text { średnie } \\
\text { zaufanie }\end{array}$ & $\%$ & chętnie & $\%$ \\
\hline księgowy & 41 & 11.99 & 38 & 20.43 & 20 & 30.30 \\
\hline lekarz & 62 & 18.13 & 30 & 16.19 & 7 & 10.61 \\
\hline pielęgniarka & 48 & 14.06 & 40 & 21.51 & 11 & 16.67 \\
\hline profesor & 65 & 19.01 & 27 & 14.512 & 7 & 10.61 \\
\hline robotnik & 56 & 16.37 & 26 & 13.98 & 17 & 25.76 \\
\hline sprzedawca & 70 & 20.47 & 25 & 13.44 & 4 & 6.06 \\
\hline suma & 342 & & 186 & & 66 & \\
\hline
\end{tabular}

\begin{tabular}{|c|c|c|c|c|c|c|}
\hline \multirow{2}{*}{ grupa zawodowa } & \multicolumn{6}{|c|}{ stopień zaufania do robota 3 [100\% podobieństwa] } \\
\cline { 2 - 8 } & $\begin{array}{c}\text { najmniejsze } \\
\text { zaufanie }\end{array}$ & $\%$ & $\begin{array}{c}\text { średnie } \\
\text { zaufanie }\end{array}$ & $\%$ & chętnie & $\%$ \\
\hline księgowy & 20 & 27.40 & 25 & 16.78 & 54 & 14.52 \\
\hline lekarz & 6 & 8.23 & 18 & 12.08 & 75 & 20.16 \\
\hline pielęgniarka & 17 & 23.27 & 23 & 15.44 & 59 & 15.86 \\
\hline profesor & 10 & 13.70 & 30 & 20.13 & 59 & 15.86 \\
\hline robotnik & 11 & 15.07 & 26 & 17.45 & 62 & 16.67 \\
\hline sprzedawca & 9 & 12.33 & 27 & 18.12 & 63 & 16.94 \\
\hline suma & 73 & & 149 & & 372 & \\
\hline
\end{tabular}

Na podstawie danych zgromadzonych w tabelach 1 i 2 dokonano szczegółowej interpretacji w zakresie trzech poziomów podobieństwa robota do człowieka i wzbudzania zjawiska doliny niesamowitości u respondentów. 


\subsubsection{Robot o najmniejszym stopniu podobieństwa do człowieka (0\%)}

Rozkład ocen wskazuje na brak zaufania do robota. Suma ocen dla wszystkich elementów skali [najmniej chętni; średnio chętnie] vs [najchętniej] przyznana w grupach zawodowych równa się kolejno: księgowy: 73-26; lekarz: 82-17; pielęgniarka: 70-29; profesor: 66-33; robotnik wykwalifikowany: 77-22; sprzedawca: 67-32. Z wyjątkiem oceny zawodu pielęgniarki, nie można mówić o wyraźnym wycofaniu respondentów. Zaprezentowane wskaźniki świadczą o niechęci do robota, jednak stosunek między oceną [-1] a oceną [0] wskazuje, że poziom akceptacji robota zależy od indywidualnych cech respondenta. Widać także, że znacząca ilościowo grupa osób z przedstawionej próby badawczej wykazuje się wysokim stopniem zaufania [1] do robota o stopniu podobieństwa $0 \%$. Wyższe zaufanie do robota może wiązać się z większą akceptacją nowych technologii przez użytkownika. Oceniając całą próbę, należy skłonić się ku stwierdzeniu, że charakteryzuje się ona pewnym stopniem niezdecydowania. Nie można wyznaczyć wyraźnej tendencji w ocenia zaufania.

\subsubsection{Robot o średnim stopniu podobieństwa do człowieka (50\%)}

Rozkład ocen wskazuje na wyraźne wycofanie respondentów. Wizerunek robota, w którym widoczne są zarówno cechy ludzkie, jak i cechy sztuczne wywołuje wśród respondentów nieprzyjemną reakcję emocjonalną. Wzrost udziału oceny [-1] i [0] w rozkładzie vs [1] nastąpił w czterech grupach zawodowych: profesor, robotnik wykwalifikowany, sprzedawca, lekarz. W przypadku grup zawodowych księgowego i pielęgniarki ocena nadal pozostaje negatywna, ale nastąpiło zmniejszenie różnicy między stopniem zaufania [-1] oraz [0]. Interpretacja w przypadku tych dwóch zawodów powinna być w przyszłości przeprowadzona na podstawie pogłębionego wywiadu, który umożliwiłby identyfikację czynników, które wpłynęły na zwiększenie poziomu akceptacji robota w porównaniu do innych grup zawodowych.

\subsubsection{Robot o dużym stopniu podobieństwa do człowieka [100\%]}

Rozkład ocen uwidacznia wyraźny wzrost zaufania respondentów. Wizerunek robota w pełni posiadającego ludzkie cechy (w tym niedoskonałości: zmarszczki, piegi i inne zmiany skórne) darzony jest przez respondentów wysokim stopniem zaufania. Porównując oceny stopnia zaufania do tego typu robota z ocenami wskazanymi dla dwóch poprzednich typów robotów nastąpił wzrost ocen [1] i spadek ocen [-1], kolejno w rolach zawodowych: księgowy, lekarz, pielęgniarka, profesor, robotnik wykwalifikowany, sprzedawca.

W celu potwierdzenia zjawiska doliny niesamowitości, zgodnie z oceną i szacunkami Karla F. MacDormana (2006), policzone zostały średnie z wszystkich ocen wyznaczonych przez respondentów - wizualizację przedstawia rysunek 4.

Wykres średniej ocen robotów zbliżony jest do ilustracji przedstawiającej dolinę niesamowitości w oryginalnej pracy Mori oraz innych replikujących ją badaniach (np. Mathur \& Reichling, 2016; Rys. 5). Lokalizacja doliny niesamowitości jest w tym samym miejscu, co w wynikach badań japońskich. Dyskomfort związany ze zmianami w wizerunku robota pojawia się około fotografii robota o średnim stopniu podobieństwa do człowieka. Wskazanie cech odpowiedzialnych za pojawienie się doliny niesamowitości wymaga przeprowadzenia 
badania pogłębionego, np. za pomocą kwestionariusza z większą liczbą zdjęć, dzięki któremu zobrazowane zostałyby powolne zmiany w wyglądzie robota. Zwiększenie bazy ilustracji w naturalny sposób pociągać powinno za sobą rozszerzenie skali ocen wizerunków robotów antropomorficznych. Jak wykazano w innych pracach (por. MacDorman, 2006) proponowane zmiany w badaniu mogą przyczynić się do uwypuklenia zjawiska doliny niesamowitości, bądź jego zaniku. Wskazuje to na poważne ograniczenia wizualnej oceny danych i wymusza konieczność poszukiwania innych sposobów lokalizacji doliny niesamowitości - co w literaturze badawczej pozostaje kwestią otwartą.

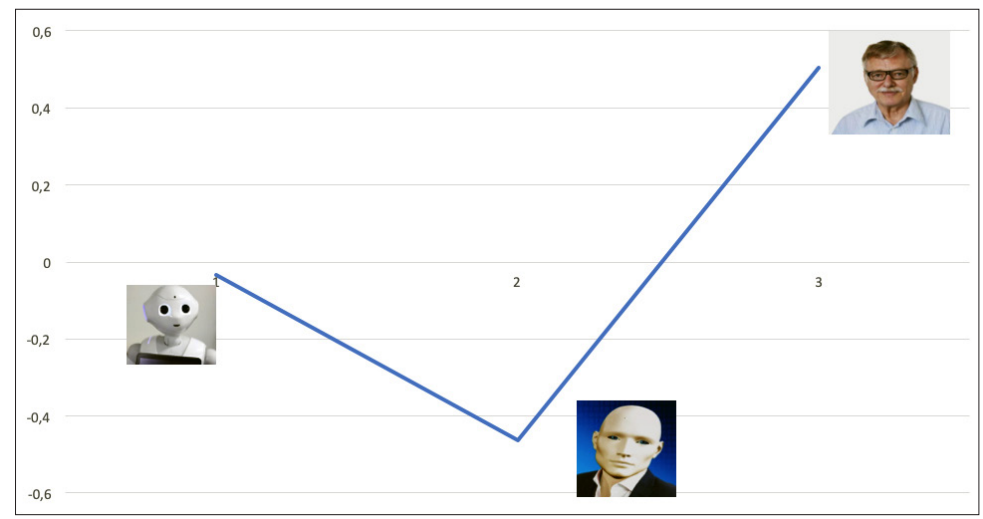

Rys. 4. Średnia z ocen dla robotów

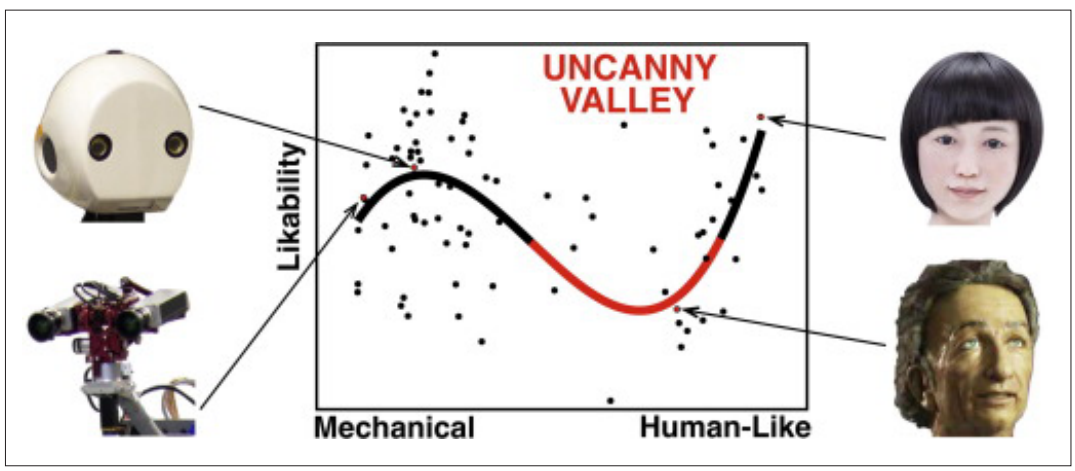

Rys. 5. Dolina niesamowitości w badaniach Mathur i Reichlinga.

Źródło: Mathur \& Reichling, 2016

\subsection{Ocena zależności między poziomem zaufania do robota a reprezentowana przez niego rola zawodowa}

Dla analizowanych przypadków sformułowano problem badawczy w postaci oceny niezależności między oceną zaufania respondenta a wizerunkiem robota z podziałem na role zawodowe: 
$\mathrm{H}_{0}$ : zmienna poziom zaufania i rola zawodowa są niezależne.

$\mathrm{H}_{1}$ : zmienna poziom zaufania i rola zawodowa nie są niezależne.

Tabela 3 przedstawia tablice kontyngencji. Zmienna dyskretna stopień zaufania do robota przyjmuje trzy stany; zmienna dyskretna rola zawodowa przyjmuje sześć stanów. Tabela liczności oczekiwanych nie zawiera wartości mniejszych niż 5, a zatem warunek Cochrana został spełniony i dlatego nie wprowadzono poprawki dla testu.

Tab. 3. Statystyka testu chi-kwadrat

\begin{tabular}{|c|c|}
\hline Stopień zaufania do robota & Statystyka testu chi-kwadrat \\
\hline Robot 1: 0\% podobieństwa & 19.18 \\
\hline Robot 2: 50\% podobieństwa & 35.17 \\
\hline Robot 3: 100\% podobieństwa & 18.81 \\
\hline stopnie swobody & 10 \\
\hline poziom istotności & 0.05 \\
\hline wartość krytyczna odczytana z tablic & 18.307 \\
\hline
\end{tabular}

Z uwagi na to, że < oraz < , przy zadanym poziomie istotności należy odrzucić hipotezę $\mathrm{H}_{0}$ o niezależności zmiennych, dla wartości $\mathrm{C}_{\text {[stopień podobieństwa 0\%] }}=0.18$ oraz $\mathrm{C}_{\text {[stopień podobieństwa }}$ ${ }_{100 \%]}=0.18$ należy wnioskować, że siła zależności jest słaba. W przypadku > hipoteza $\mathrm{H}_{0}$ o niezależności zmiennych została odrzucona, dla wartości $C=0.24$ należy wnioskować, że siła zależności jest słaba.

\subsection{Zależności między poziomem neutralności/inwazyjności ról zawodowych robotów a sympatia do nich}

Dla analizowanych przypadków sformułowano problem badawczy w postaci oceny niezależności między oceną zaufania respondenta a wizerunkiem robota z podziałem na role zawodowe (według podziału dodatkowego: zawody związane z usługami medycznymi, zawody usługowe, zawody związane z wiedzą):

$\mathrm{H}_{0}$ : zmienna poziom zaufania i rola zawodowa są niezależne.

$\mathrm{H}_{1}$ : zmienna poziom zaufania i rola zawodowa nie są niezależne.

Tab. 4. Test chi-kwadrat

\begin{tabular}{|l|l|c|c|c|}
\cline { 3 - 5 } \multicolumn{2}{c|}{} & \multicolumn{3}{c|}{ Statystyka chi-kwadrat } \\
\hline \multirow{2}{*}{ Rola zawodowa } & Robot 1 & Robot 2 & Robot 3 \\
\hline Usługi medyczne & pielęgniarka, lekarz & 5.86 & 4.10 & 7.78 \\
\hline Usługowe & sprzedawca, robotnik & 4.66 & 9.62 & 0.23 \\
\hline Związane z wiedzą & profesor, księgowy & 4.29 & 13.45 & 4.01 \\
\hline & stopnie swobody & \multicolumn{3}{|c|}{0.05} \\
\cline { 2 - 5 } & poziom istotności & \multicolumn{3}{|c|}{7.8147} \\
\cline { 2 - 5 } & wartość krytyczna odczytana z tablic & \multicolumn{3}{|c}{} \\
\cline { 2 - 5 } & & &
\end{tabular}


W przypadku ról zawodowych związanych z usługami i związanych z wiedzą w ocenie robota 2 odrzucono hipotezę zerową o niezależności zmiennych. W pozostałych przypadkach: > przy zadanym poziomie istotności, decyzja weryfikacyjna wskazuje na brak podstaw do odrzucenia hipotezy $\mathrm{H}_{0}$ o niezależności zmiennych.

Badanie wykazało, że stopień zaufania do robota ogólnie jest zależny od jego roli zawodowej. Jednak stopień zaufania do robota nie jest zależny od tego, czy jest on przeznaczony do wykonywania ról zawodowych związanych z usługami medycznymi (lekarz, pielęgniarka), które mogą być interpretowane jako inwazyjne wobec klienta czy neutralne zawody usługowe (sprzedawca, robotnik). Test chi-kwadrat potwierdził taką zależność tylko dla robotów o stopniu podobieństwa do człowieka 50\%, reprezentujących role zawodowe związane z wiedzą i usługami.

Mori w swojej pracy wskazał, że przeznaczenie robota może wpływać na granicę tolerancji względem wyglądu robota. Jako przykład podał roboty używane w przemyśle, w przypadku których liczy się funkcjonalność, a nie wygląd, i zestawił z nimi np. roboty-zabawki, których funkcjonalność nie liczy się tak bardzo jak wygląd. Roboty przemysłowe charakteryzują się najmniejszym stopniem podobieństwa do człowieka, użytkownik nie rozwija wobec nich uczuć, nie odczuwa przyzwyczajenia (Mori, 2012, 98). Innymi słowy, przeznaczenie robota może być rozpatrywane jako czynnik wpływający na kształt funkcji, na której weryfikowana jest dolina niesamowitości. Odwołując się do takiego rozumowania w dyskusji, należy uwzględniać podział na role zawodowe. Fakt, że w zaproponowanym badaniu dla pewnych par odrzucono hipotezę o niezależności, przekłada się na wniosek, że podział z uwzględnieniem ról zawodowych jest właściwy. Zaprezentowane wyniki oraz przyjęcie dodatkowego czynnika wpływającego na kształt funkcji skłaniają do postulatu podjęcia kolejnego badania, w którym możliwe będzie pogłębienie wiedzy o rozmiarze efektu doliny niesamowitości. Podobne badanie było przeprowadzone przed dekadą przez japońsko-holenderski zespół badaczy (Bartneck et al., 2007, 368-373).

Zarówno Mori, jak i badacze później zajmujący się problemem doliny niesamowitości skłaniają się ku stwierdzeniu, że przypisana ocena stopnia zaufania do robotów jest efektem własnych doświadczeń respondentów (Bartneck et al., 2007; Mori, 2012). A zatem zjawisko doliny niesamowitości powinno charakteryzować się zmiennością w czasie. Z drugiej jednak strony, często posługujemy się schematami poznawczymi, które sytuują nasze oczekiwania w pewnych stereotypowych ramach. Według wiedzy autora, nie ma szeroko zakrojonych badań, które weryfikowałby zanik zjawiska doliny niesamowitości z czasem lub wraz ze wzrostem doświadczenia, ani badań nad przesunięciem granicy tolerancji wobec wyglądu robota, która mogłaby być mierzona przez przesunięcie minimum funkcji względem osi x. Na zmienność ocen może wpływać zwiększenie liczby robotów wykorzystywanych w danym obszarze (np. w szpitalu itp.).

\section{Podsumowanie}

Badania przeprowadzone wśród polskich studentów wskazują, że istnieje przesłanka świadcząca o występowaniu zjawiska doliny niesamowitości. Na podstawie przyjętej próby badawczej i wybranego terenu badawczego trudno o uogólnienia, jednak wiele innych badań, prowadzonych przy użyciu odmiennych perspektyw poznawczych i metodologii 
potwierdza, że zjawisko to istnieje. Innymi słowy, prawdopodobne jest założenie, że robot upodobniony do człowieka ma wpływ na poczucie bezpieczeństwa człowieka. Im to podobieństwo jest większe, tym sympatia człowieka do robota zwiększa się, aż do pewnego momentu krytycznego, w którym pojawia się obawa lub lęk. Na wyznaczanie momentu krytycznego może mieć wpływ rola zawodowa pełniona przez robota. Badanie wykazało, że stopień zaufania do robota jest związany z wykonywaną przez niego pracą, choć nie dostrzeżono wyraźnych różnic w poziomie zaufania do robotów wykonujących prace różnych profesji. Ponieważ celem artykułu było także przedstawienie procedury badawczej, założono, że przy zastosowaniu narzędzia pozwalającego na ukazanie danych innych niż dane wskazane na skali nominalnej zauważenie zależności stopnia inwazyjności określonej pracy robota byłoby łatwiejsze. W przyszłych badaniach należy podjąć szersze skalowanie dla proponowanych wartości. Jednocześnie należy monitorować ewentualne zmiany w zakresie zawodów cechujących się prestiżem społecznym i korygować reprezentację zawodów. W przytoczonych badaniach CBOS takie zmiany w czasie są widoczne (CBOS, 2013). Poza tym, prestiż zawodów jest zmienny zależnie od hierarchizującej je grupy etnicznej.

W przyszłości badania kwestionariuszowe powinny uwzględniać też takie elementy, jak: wiarygodność robota, radość z interakcji z nim i obecność społeczna robota (Bartneck et al., 2008, 78). Biorąc natomiast pod uwagę kompetencje robota, jego wiedzę i umiejętności oraz to, że istotą sztucznej inteligencji - jak pisze Jerry Kaplan - „jest zdolność do dokonywania właściwych uogólnień w odpowiednim czasie na podstawie ograniczonych danych" (Kaplan, 2019, 21), przygotowywanie społeczeństwa do korzystania z wyspecjalizowanych, wysoce profesjonalnych usług świadczonych przez roboty jest zadaniem, które powinno być podjęte w najbliższej przyszłości. To i kolejne podobne badania powinny więc służyć pomocą programistom, a także osobom zajmującym się szeroko pojętą edukacją.

\section{Załącznik: Kwestionariusz ankiety}

Badanie dotyczy poziomu sympatii wobec robotów wyposażonych w sztuczna inteligencje, które w przyszłości będa mogty pracować w zawodach dzisiaj wykonywanych przez ludzi.

Wyobraź sobie, że Twoim profesorem na uniwersytecie będzie robot wyposażony w sztuczną inteligencję. Na cykl wykładów i egzamin którego z poniższych robotów zapisałbyś się: najchętniej (+1), do którego mniej chętnie (0), a do którego najmniej chętnie (-1)? Każdemu z robotów musisz przypisać inną notę: +1, 0 lub -1.
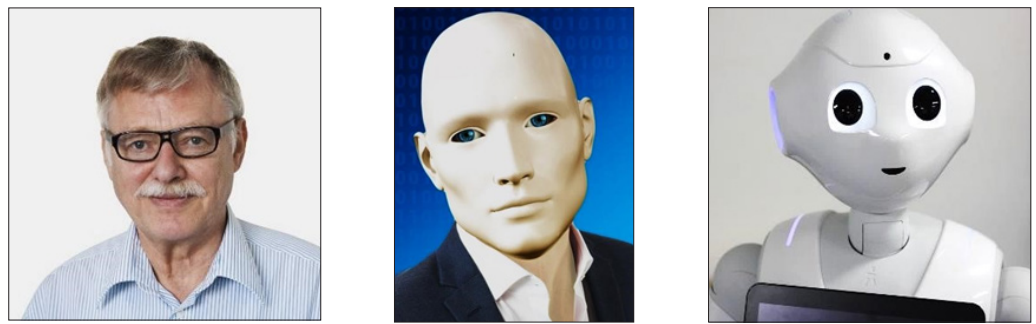
Wyobraź sobie, że pielęgniarka, która ma za chwilę pobrać Tobie krew jest robotem wyposażonym w sztuczną inteligencję. Zabiegowi której z trzech poniższych pielęgniarek poddałbyś się z: największym zaufaniem (+1), mniejszym zaufaniem (0), najmniejszym zaufaniem (-1)?
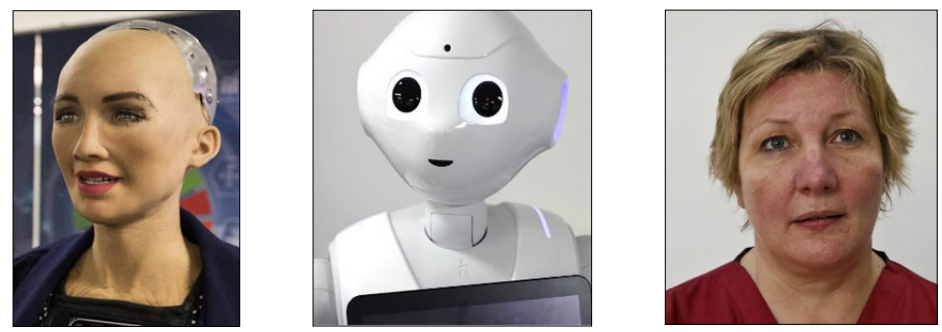

Wyobraź sobie, że robotnikiem, który ma wykonać remont Twojego mieszkania będzie robot wyposażony w sztuczną inteligencję. Któremu z trzech poniższych robotów zlecisz pracę z: największym zaufaniem (+1), mniejszym zaufaniem (0), najmniejszym zaufaniem (-1)?
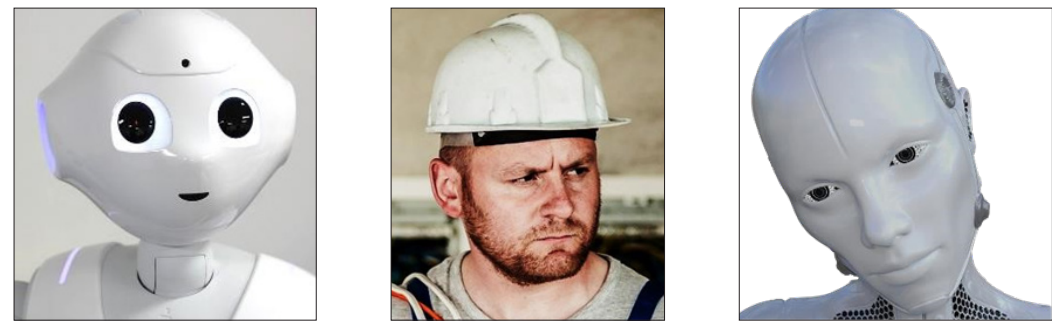

Wyobraź sobie, że księgowym, który ma zoptymalizować Twoje zeznanie podatkowe będzie robot wyposażony w sztuczną inteligencję. Któremu z poniższych robotów zleciłbyś usługę z: największym zaufaniem (+1), mniejszym zaufaniem (0), najmniejszym zaufaniem $(-1)$ ?
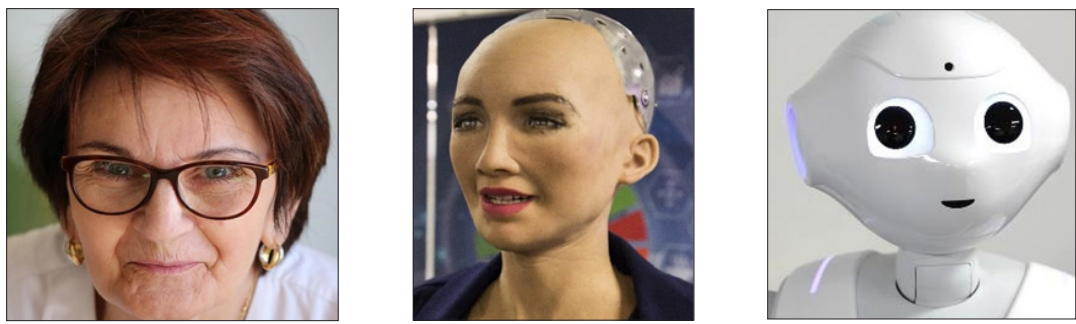
Wyobraź sobie, że sprzedawcą w sklepie jest robot wyposażony w sztuczną inteligencję. Do którego z trzech poniższych robotów podejdziesz: najchętniej $(+1)$, mniej chętnie (0), najmniej chętnie $(-1)$ ?
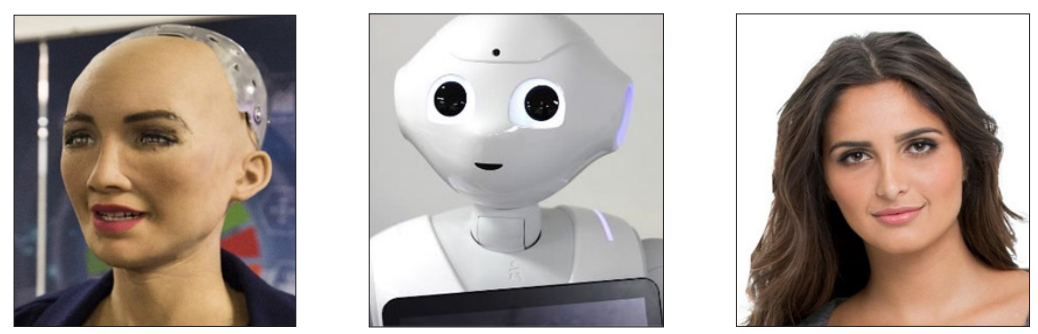

Wyobraź sobie, że lekarz, który ma przeanalizować Twoją kartę chorobową i wyniki badań jest robotem wyposażonym w sztuczną inteligencję. Któremu z trzech poniższych robotów przekazałbyś do analizy Twoje dane zdrowotne: najchętniej (+1), mniej chętnie (0), najmniej chętnie (-1)?
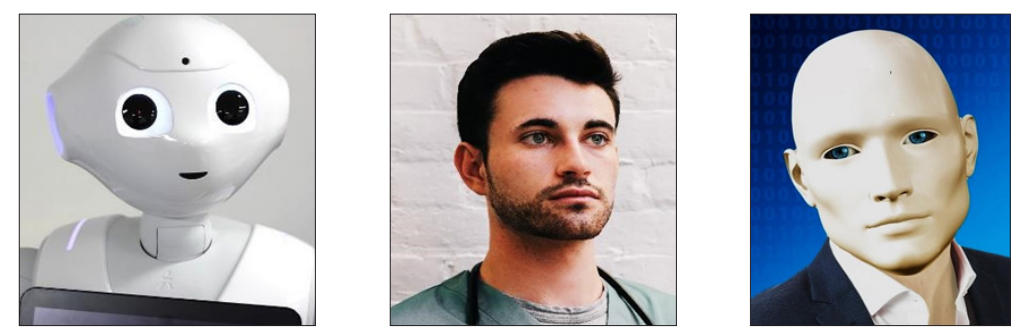

\section{Bibliografia}

Bartneck, Ch., Kanda, T., Ishiguro, H., Hagita, N. (2007). Is the Uncanny Valley an Uncanny Cliff? In: RO-MAN 2007 - The 16th IEEE International Symposium on Robot and Human Interactive Communication. August 26-29, 2007, Jeju Island, South Korea, Proceedings (368-373). IEEE. 10.1109/ROMAN.2007.4415111.

Bartneck, Ch. Kulić, D., Croft, E., Zoghbi, S. (2008). Measurement Instruments for the Anthropomorphism, Animacy, Likeability, Perceived Intelligence, and Perceived Safety of Robots. International Journal of Social Robotics, January, 71-81.

Burleigh, T. J., Schoenherr, J. R., Lacroix, G. L. (2013). Does the Uncanny Valley Exist? An Empirical Test of the Relationship Between Eeriness and the Human Likeness of Digitally Created Faces. Computers in Human Behavior, 29 (3), 759-771.

CBOS (2013). Komunikat z badań: BS/164/2013: prestiż zawodów, oprac. A. Cybulska [online]. CBOS [11.02.2019], https://www.cbos.pl/SPISKOM.POL/2013/K_164_13.PDF

Frey, C. B, Osborne, M. A. (2013). The Future of Employment. How Susceptible Are Jobs to Computerisation? [online]. Oxford Martin School [13.02.2019], https://www.oxfordmartin.ox.ac.uk/ downloads/academic/The_Future_of_Employment.pdf 
Iafrate, F. (2018). Artificial Intelligence and Big Data: The Birth of a New Intelligence. London: JohnWiley \& Sons.

Kaplan, J. (2019). Sztuczna inteligencja. Co każdy powinien wiedzieć. Warszawa: PWN.

MacDorman, K. F. (2006). Subjective Ratings of Robot Video Clips for Human Likeness,

Familiarity, and Eeriness: An Exploration of the Uncanny Valley. In: ICCS/CogSci-2006 Long Symposium: Toward Social Mechanisms of Android Science (26-29). July 26, 2006. Vancouver, Canada.

MacDorman, K. F., Chattopadhyay, D. (2016). Reducing Consistency in Human Realism Increases the Uncanny Valley Effect; Increasing Category Uncertainty Does Not. Cognition, 146, 190-205.

Mathur, M. B., Reichling, D. B. (2016). Navigating a Social World with Robot Partners. A Quantitative Cartography of the Uncanny Valley. Cognition, January, 22-32.

Mori, M. (2012). The Uncanny Valley [From the Field]. transl. K.M. MacDorman \& N. Kageki. IEEE Robotics \& Automation Magazine, 2, 98-100.

Siau, K., Wang, W. (2018). Building Trust in Artificial Intelligence, Machine Learning, and Robotics. Cutter Business Technology Journal, 2, 47-53.

Sobczyk, M. (2012). Statystyka, Warszawa: PWN.

Wójcik, M. (2018a). Rozszerzona rzeczywistość w ustugach informacyjnych bibliotek, Kraków: Wyd. UJ.

Wójcik, M. (2018b). Sztuczna inteligencja - potencjał dla procesów zarządzania informacją. Przegląd Biblioteczny, 1, 5-15.

Yamada, Y., Kawabe, T., Ihaya, K. (2013). Categorization Difficulty is Associated with Negative Evaluation in the "Uncanny Valley" Phenomenon. Japanese Psychological Research, 1, 20-32.

\title{
Assessment of the Relationship Between the Image of the Robot and Trust Towards the Robot in Relation to the Concept of the Uncanny Valley by the Example of Respected Occupations
}

\begin{abstract}
Purpose/Thesis: The purpose of the article is to verify whether the 'uncanny valley' phenomenon arises in relation to robots in respected occupations. Additionally, the article investigates whether the sense of human security depends on the type of services to be performed by the robot.

Approach/Methods: The research is based on a survey conducted with a group of students from various university courses, in both humanities and sciences. The survey used a questionnaire featuring visualizations of anthropomorphic robots, whose similarity to a human being varied. The survey questioned the degree of trust towards robots in six professions: a university professor, a medical doctor, a nurse, a skilled worker, an accountant, a salesman.

Results and conclusions: The research confirmed that the 'uncanny valley' phenomenon does arise and that the degree of trust depends on the type of work performed by the robot.

Originality/Value: As far as the author is aware, the 'uncanny valley' phenomenon, accounting for the robots' occupations as a changing variable, has not been studied in Poland before.
\end{abstract}

Keywords

Artificial Intelligence. Emotions. Face perception. Humanoid robots. Professional roles. Uncanny valley.

Dr hab. TOMASZ KRUSZEWSKI, prof. UMK, bibliolog i informatolog, psychoterapeuta poznawczo-behawioralny. Najważniejsze publikacje: Deliciae Thorunienses: poszukiwania tożsamości miasta w literaturze 
podróżniczej (Toruń 2013), Przestrzenie biblioteki: o symbolicznej, fizycznej i społecznej obecności instytucji (Toruń 2012), Gtubczycka biblioteka starodruków franciszkanów mniejszych - podsumowanie programu (Z Badań nad Książką i Księgozbiorami Historycznymi, 2010).

Kontakt $z$ autorem

tomkrus@umk.pl

Katedra Kognitywistyki

Instytut Badań Informacji i Komunikacji

Uniwersytet Mikotaja Kopernika w Toruniu

ul. Bojarskiego 1

87-100 Toruń 